\title{
Case Analysis of Environmental Impact Assessment for Ideological and Political Education
}

\author{
Haiying Zhang ${ }^{1 *}$, Hao Shi ${ }^{1}$ \\ ${ }^{1}$ School of Chemical and Environmental Engineering, Shanghai Institute of Technology, Shanghai, China
}

\begin{abstract}
The section of importance and rules of environmental impact assessment is chosen to analyse ideological and political education, and the three aims are analysed. It involves teaching aims, teaching target analysis, teaching content and data, teaching process and measures, and teaching results. It is concluded that most of the students, after learning of this section, have a relatively good grasp of the $2^{\text {nd }}$ aim, i.e. a good grasp of importance of environmental impact assessment on environment protection and economic development. However, they need more time to set up consciousness of social responsibility and the sense of professional ethics.
\end{abstract}

\section{Introduction}

Environmental Impact Assessment is a required course for students whose major is Environmental Engineering [1]. It involves eleven chapters: general introduction to environmental impact assessment, environmental laws and regulations, procedures and measures for environmental assessment, engineering analysis, atmospheric environmental impact assessment, surface water environmental impact assessment, noise environmental impact assessment, environmental impact assessment of solid waste, ecological environmental impact assessment, environmental risk assessment, planning environmental impact assessment. Through learning this course, the students should grasp basic definitions and theories of environmental impact assessment, environmental laws and regulation, and procedures and measures of assessment. It aims to improve students' practical ability of environmental impact assessment on industrial project and ecological project $[1,2]$.

In terms of ideological and political education, it has four aims. Firstly, it aims to cultivate the feelings of nation and country, social responsibility and environmental protection consciousness. Secondly, it aims to cultivate students' scientific spirit, "less id more", and truthseeking. Thirdly, it aims to cultivate technology accomplishment and engineering thinking of students. Finally, it aims at students' occupational emotion, regulation awareness and team work $[3,4]$.

This paper provides teaching design for one section of importance and rules for environmental impact design, involving teaching aims, teaching target analysis, teaching content and data, teaching process and measures, and teaching results.

\section{Teaching aims of importance and rules for environmental impact assessment}

This course is provided to junior students whose major is environmental engineering. The junior students have learned basic courses and partial professional courses, and grasp basic environmental knowledge and pollution control technologies in terms of water, gas, noise and solid waste. After learning these pollution control technologies and pollution mechanism, this course is provided to cultivate the students' ability of solving practical environmental problems. This course gives an integrated use of environmental protection knowledge in practical environmental impact assessment, and thus improve students' ability of solving practical problems using what they learned. Taking the section of importance and rules for environmental impact assessment as an example, the aims are shown in table 1 .

Table 1. aims and relative contents

\begin{tabular}{llc}
\hline & \multicolumn{1}{c}{ Relative contents } & aims \\
\hline $\begin{array}{l}\text { Knowledge } \\
\text { transfer }\end{array}$ & $\begin{array}{l}\text { The students are required to grasp definitions and types of environmental impact } \\
\text { assessment, basic rules, technical rules, and their functions, and the importance to } \\
\text { environment protection and economic development. }\end{array}$ & $1^{\text {st }}$ aim \\
\hline
\end{tabular}

\footnotetext{
*Corresponding author's e-mail: zhanghaiying@sit.edu.cn
} 


\begin{tabular}{|c|c|c|}
\hline $\begin{array}{l}\text { Ability } \\
\text { training }\end{array}$ & $\begin{array}{l}\text { It let students know importance of environmental impact assessment on } \\
\text { environment protection and economic development, and thus cultivate their } \\
\text { professional values of environmental protection, observing principles and taking } \\
\text { environmental protection and sustainable development as the responsibility. }\end{array}$ & $2^{\text {nd }}$ aim \\
\hline $\begin{array}{l}\text { Emotional } \\
\text { thinking }\end{array}$ & $\begin{array}{l}\text { It let students know importance of observing basic principles and technical } \\
\text { principles in environmental impact assessment, and thus set up consciousness of } \\
\text { social responsibility and sense of professional ethics. }\end{array}$ & $3^{\text {rd }}$ aim \\
\hline
\end{tabular}

\section{Teaching content and idea}

This section involves three parts. The first part is introduction of definition, types and three stages in environmental impact assessment, and the aim thereof. The second part is introduction of basic rules and technical rules that should be observed in environmental impact assessment, and the importance. The third part is special cases, in which serious results are witnessed without environmental impact assessment.

The teaching ideas is shown in Fig.1. Through learning of this section, the students should firstly remember what they learned and then understand the knowledge. They can apply what they learned only after understanding the knowledge. Finally, the professional value is built during application of the knowledge.

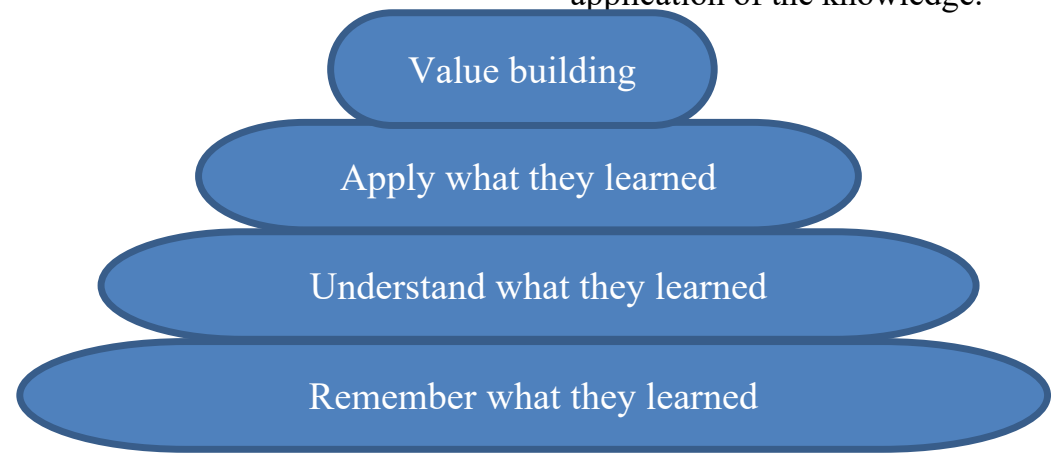

Fig.1 teaching idea of this section

\section{Teaching process and measures analysis}

Teaching measures involve class ppt for teaching, video of engineering cases and pictures.

\subsection{Question import}

This course begins with introduction of the law of the People's Republic of China on Environmental impact assessment, which is promulgated for effect on September 1,2003 . It has been enacted for sustainable development of economy, preventing negative impacts of programs and construction projects. What's environmental impact assessment? How many types is environmental impact assessment divided into? These questions lead students to think. The questions and the related content are shown in Table 2 . Through this way, it is relatively easy to attract students' interest.

Table 2. Questions and relative content

\begin{tabular}{llc}
\hline \multicolumn{1}{c}{ Questions } & Relative content \\
\hline 1 & What's environmental impact assessment? & $\begin{array}{c}\text { Definition of environmental } \\
\text { impact assessment. }\end{array}$ \\
2 & $\begin{array}{l}\text { How many types is environmental impact assessment } \\
\text { divided into? }\end{array}$ & $\begin{array}{c}\text { Types of environmental impact } \\
\text { assessment. }\end{array}$ \\
& What rules should it comply with? & Basic rules and technical rules.
\end{tabular}

\subsection{Teaching process}

In the first part of this section, definition of environment, environmental capacity, and environmental impact assessment are introduced. Environmental impact assessment for plan, and that for construction projects are explained. Both types have three stages, engineering analysis, environmental present situation analysis, environmental estimate and assessment. In the second part, 
the basic rules and technical rules that should be observed in environmental impact assessment, are introduced. The assessment process should be objective, open and impartial. In the third part, special cases for different content are given to make it easy for students' understanding of this section.

\subsection{Cases used for this section}

Four cases are used to explain the content of this section, as shown in Table 3 . The case of chemical engineering projects are major source of pollution, involving gas pollution, water pollution, solid waste pollution and noise pollution. In addition, many risks exist due to existence of serious risk sources such as dangerous process, dangerous material storage and hazardous waste management. Hence, environmental impact assessment is particular important for these projects to control all kinds of pollution and to reduce risk of hazardous. The case of environmental impact assessment for a city plan is quite different from for that for construction projects in terms of assessment process, methods and laws. Hence, case 2 is used to analyse the difference between the two types. Case 3 is used to explain the three stages for environmental impact assessment, site survey, engineering analysis and environmental present situation analysis, environmental estimate and assessment.

Table 3. the content cases used to analyse

\begin{tabular}{llc}
\hline & \multicolumn{1}{c}{ Cases } & Relative content \\
\hline Case 1 & $\begin{array}{l}\text { Environmental impact assessment for a chemical } \\
\text { engineering factory. } \\
\text { Environmental impact assessment for a city plan. }\end{array}$ & $\begin{array}{c}\text { Importance of environmental } \\
\text { impact assessment. } \\
\text { Case } 2\end{array}$ \\
Case 3 & $\begin{array}{l}\text { Environmental impact assessment for the expressway } \\
\text { engineering construction project. }\end{array}$ & Three stages. \\
Case 4 & Environmental impact assessment for wig factory. & Basic rules and technical rules.
\end{tabular}

\section{Teaching result analysis}

A test is given after learning this section to examine the teaching effect, and the aim-achievement analysis is shown in Table 4.

Table 4. Aim-achievement analysis

\begin{tabular}{|c|c|c|c|c|c|c|c|}
\hline \multirow[b]{2}{*}{ NO. } & \multirow[b]{2}{*}{ Student ID } & \multicolumn{2}{|c|}{$1^{\text {st }}$ aim } & \multicolumn{2}{|c|}{$2^{\text {nd }}$ aim } & \multicolumn{2}{|c|}{$3^{\text {rd }}$ aim } \\
\hline & & $\begin{array}{l}\text { Score } \\
(30 \%)\end{array}$ & $\begin{array}{c}\text { Achievement } \\
\text { degree }\end{array}$ & $\begin{array}{l}\text { Score } \\
(40 \%)\end{array}$ & $\begin{array}{l}\text { Achievement } \\
\text { degree }\end{array}$ & $\begin{array}{l}\text { Score } \\
(30 \%)\end{array}$ & $\begin{array}{c}\text { Achievement } \\
\text { degree }\end{array}$ \\
\hline 1 & 1510700301 & 23 & 0.77 & 36 & 0.90 & 19 & 0.63 \\
\hline 2 & 1510700308 & 19 & 0.63 & 21 & 0.53 & 15 & 0.50 \\
\hline 3 & 1510700508 & 18 & 0.60 & 27 & 0.68 & 17 & 0.57 \\
\hline 4 & 1510700511 & 27 & 0.90 & 34 & 0.85 & 19 & 0.63 \\
\hline 5 & 1510700518 & 24 & 0.80 & 38 & 0.95 & 12 & 0.40 \\
\hline 6 & 1510700816 & 26 & 0.87 & 36 & 0.90 & 19 & 0.63 \\
\hline 7 & 1510700925 & 18 & 0.60 & 35 & 0.88 & 18 & 0.60 \\
\hline 8 & 1510700931 & 20 & 0.67 & 34 & 0.85 & 21 & 0.70 \\
\hline 9 & 1610700939 & 21 & 0.70 & 33 & 0.83 & 21 & 0.70 \\
\hline 10 & 1710741101 & 19 & 0.63 & 33 & 0.83 & 23 & 0.77 \\
\hline 11 & 1710741102 & 23 & 0.77 & 35 & 0.88 & 21 & 0.70 \\
\hline 12 & 1710741103 & 28 & 0.93 & 40 & 1.00 & 20 & 0.67 \\
\hline 13 & 1710741104 & 29 & 0.97 & 38 & 0.95 & 21 & 0.70 \\
\hline 14 & 1710741105 & 21 & 0.70 & 39 & 0.98 & 24 & 0.80 \\
\hline 15 & 1710741106 & 22 & 0.73 & 36 & 0.90 & 25 & 0.83 \\
\hline 16 & 1710741107 & 16 & 0.53 & 36 & 0.90 & 21 & 0.70 \\
\hline 17 & 1710741108 & 18 & 0.60 & 24 & 0.60 & 20 & 0.67 \\
\hline 18 & 1710741109 & 25 & 0.83 & 37 & 0.93 & 19 & 0.63 \\
\hline
\end{tabular}




\begin{tabular}{llllllll}
19 & 1710741110 & 27 & 0.90 & 26 & 0.65 & 22 & 0.73 \\
20 & 1710741112 & 28 & 0.93 & 33 & 0.83 & 15 & 0.50 \\
21 & 1710741113 & 21 & 0.70 & 15 & 0.38 & 17 & 0.57 \\
22 & 1710741114 & 20 & 0.67 & 24 & 0.60 & 17 & 0.57 \\
23 & 1710741115 & 20 & 0.67 & 38 & 0.95 & 27 & 0.90 \\
24 & 1710741117 & 19 & 0.63 & 26 & 0.65 & 19 & 0.63 \\
25 & 1710741118 & 22 & 0.73 & 22 & 0.55 & 17 & 0.57 \\
26 & 1710741119 & 25 & 0.83 & 33 & 0.83 & 26 & 0.87 \\
27 & 1710741120 & 28 & 0.93 & 33 & 0.83 & 25 & 0.83 \\
28 & 1710741121 & 23 & 0.77 & 36 & 0.90 & 22 & 0.73 \\
29 & 1710741122 & 26 & 0.87 & 34 & 0.85 & 27 & 0.90 \\
30 & 1710741123 & 24 & 0.80 & 32 & 0.80 & 21 & 0.70 \\
\multicolumn{2}{c}{ Average value } & 23 & 0.75 & 32 & 0.8 & 20 & 0.68 \\
\hline
\end{tabular}

The aim-degree is 0.75 for the $1^{\text {st }}$ aim, 0.8 for the $2^{\text {nd }}$ aim and 0.68 for the $3^{\text {rd }}$ aim. It shows that the student has a good grasp of the $2^{\text {nd }}$ aim, and a poor grasp of the $3^{\text {rd }}$ aim. Most of the students know importance of environmental impact assessment on environment protection and economic development. Observing principles and taking environmental protection and sustainable development as the responsibility cultivate their professional values of environmental protection. However, they need more time to set up consciousness of social responsibility and sense of professional ethics.

\section{Conclusions}

This paper provides teaching design for the section of importance and rules for environmental impact design, involving teaching aims, teaching target analysis, teaching content and data, teaching process and measures, and teaching results. Three aims of knowledge transfer, ability training, and emotional thinking are analysed. It indicates that most of the students, after learning of this section, have a relatively good grasp of the 2 nd aim, i.e. a good grasp of importance of environmental impact assessment on environment protection and economic development. However, they need more time to set up consciousness of social responsibility and sense of professional ethics.

\section{Acknowledgments}

We thank the Pilot program-model course of Environmental Impact Assessment under the project number 1021ZK202004073-A22 for financial support.

\section{References}

1. Li Shuqin, Meng Xianlin. Environmental Impact Assessment. Beijing: Electronic Industry Press. 2016, P.20.

2. Chen Ke. Teaching method analysis of ideological and political education and Environmental Impact Assessment. Jiangxi Chemical Industry, 2020 (3), 137-139.

3. Liao Fang. Ideological and political education for college education. Data of Culture and Education, 2020 (10), 140-147.

4. Ye Lian. Ideological and political education and quality education. University Education, 2020 (3), 121-123. 